\title{
Concepções de crianças da educação infantil sobre violência e a relação com o brincar: contribuições de Freud e Winnicott
}

\author{
Taisa Resende Sousa \\ Regina Lúcia Sucupira Pedroza \\ Maíra Muhringer Volpe
}

\section{RESUMO}

Este relato de pesquisa objetivou compreender as concepções de crianças sobre violência, tecendo relações entre a violência e o brincar, a partir de Freud e Winnicott. 0 brincar é entendido aqui como uma expressão característica das crianças e também uma experiência criativa, relacionada ao sentimento de continuidade do ser e à transicionalidade. Já a violência é concebida como o conflito entre a satisfação das pulsões primitivas e as exigências civilizatórias. Existem diversas possibilidades de lidar com ela, sendo o brincar um dos caminhos possíveis. A metodologia qualitativa consistiu na observação participante em um centro de educação infantil, da rede pública, no Distrito Federal (DF); na realização de quatro oficinas lúdicas com crianças de quatro e cinco anos, em uma turma do primeiro período; além da leitura do projeto político-pedagógico (PPP) dessa escola. Como resultados e discussão, evidenciamos encontros e desencontros entre o escrito no PPP e a vivência na observação participante; e as concepções de crianças sobre violência. A pesquisa empírica reforçou a pertinência em tecermos relações entre a violência e o brincar, entendendo o brincar como uma das maneiras de elaborações de possíveis conteúdos ligados à violência

Palavras-chave: Crianças; educação infantil; psicanálise; violência; brincar

\section{ABSTRACT}

\section{Preschooler's conceptions about violence and its relation with playing: Freud's and Win-} nicott's contributions

This research report aimed to understand children's conceptions of violence, establishing a relation between violence and playing, from Freud and Winnicott. Playing is understood as one expression of children, and also a creative experience, related to the feeling of continuity of being and to the transitional. Violence is conceived as the conflict between the satisfaction of the primitive drives and the demands of civilization. There are several possibilities to deal with it, and playing is one of the possible ways. The qualitative methodology consisted of participant observation carried out in a Early Childhood Education Center, of a public school in Distrito Federal, Brazil, consisting of four ludic workshops with four and five-year-old children in a first-year class; and also the reading of the political-pedagogical project (PPP) of this school. As results and discussion, we found that in some occasions what was written at the PPP was not experienced at the daily routine of the school; we also found the children's conceptions about violence. This empirical research reinforced the importance of studies relating violence and playing, understanding it as a way to elaborate violent content and as a creative experience, based on the children own resources.

Keywords: Children; preschool; psychosanalysis; violence; play

\section{Sobre os Autores}

T.R.S.

orcid.org/0000-0002-0635-7209

Universidade de Brasília

(UnB) - Brasília, DF

taisarsousa@gmail.com

R.L.S.P.

orcid.org/0000-0003-2251-5040

Universidade de Brasília

(UnB) - Brasília, DF

57pedroza@gmail.com

M.M.V.

orcid.org/0000-0002-4052-8518

Universidade de Brasília

(UnB) - Brasília, DF

maira@muhringer.com.br

\section{Direitos Autorais}

Este é um artigo aberto e pode ser reproduzido livremente, distribuído, transmitido ou modificado, por qualquer pessoa desde que usado sem fins comerciais. 0 trabalho é disponibilizado sob a licença Creative Commons CCBY-NC 
"Porque se a gente fala a partir de ser criança, a gente faz comunhão: de um orvalho e sua aranha, de uma tarde e suas garças, de um pássaro e sua árvore. Então eu trago das minhas raízes crianceiras a visão comungante e oblíqua das coisas" (Barros, 2003).

Este relato de pesquisa teve como objetivo geral compreender as concepções de crianças, em uma turma do primeiro período da educação infantil, sobre violência, abarcando reflexões sobre o brincar, a partir da leitura de Sigmund Freud e Donald W. Winnicott. A proposta desta pesquisa foi trazer a visão crianceira, como Manoel de Barros (2003) diz, acerca da temática da violência e suas aproximações com o conceito do brincar.

Entendemos que, ao brincar, a criança pode elaborar suas experiências (Freud, 1920/1996) e, entre elas, possíveis conteúdos ligados à violência. Além disso, essa atividade lúdica torna-se uma experiência criativa, uma forma básica de viver, relacionada ao sentimento de continuidade do ser e à noção de transicionalidade (Winnicott, 1975).

Freud (1908/1996), interessado no papel das fantasias ao escrever Escritores criativos e devaneios, indaga se já na infância haveria traços de atividade criativa e tece uma relação com o brincar, afirmando que a ocupação favorita da criança é o jogo ou o brinquedo e que ela leva a sério esse mundo do brincar, envolvendo emoção em sua atividade. 0 autor introduz a ideia de que o brincar na infância corresponde à fantasia e à escrita criativa na vida adulta e tais fenômenos criam um mundo próprio, ou ainda, possibilitam que o sujeito adapte alguns elementos de seu mundo, tornando-os mais agradáveis.

No brincar há também um desejo que auxilia a criança em seu desenvolvimento: o desejo de ser adulto. Por outro lado, ao crescer, os adultos, mesmo tendendo a parar de brincar (como crianças), apenas trocam um elemento por outro, ou seja, "a criança em crescimento, quando para de brincar, só abdica o elo com os objetos reais; em vez de brincar, ela agora fantasia. Constrói castelos no ar e cria o que chamamos de devaneios" (Freud, 1908/1996, p. 136).

A teoria freudiana acerca do brincar está ligada ao processo de desenvolvimento das crianças, que criam mundos imaginários e revivem o mundo dos adultos ao brincar de papai-mamãe, de médico, de casinha, de escolinha e de polícia-ladrão, entre outras tantas possibilidades. É comum que crianças se transformem em policial, na brincadeira, e corram atrás de bandidos imaginários; geraria, no entanto, estranhamento um adulto com esse comportamento. Os adultos expressar-se-iam de outro modo: em devaneios ou expressões artísticas, por exemplo (Oliveira \& Fux, 2014).
Em Além do Princípio do Prazer, ao observar o neto de um ano e meio de idade que brincava, Freud (1920/1996) indagase: por que as crianças brincam? É a partir da observação detalhada da brincadeira infantil que ele reconhece e interpreta o jogo do fort-da, intimamente relacionado ao fato de deixar a mãe ir embora e recuperá-la, uma encenação do desaparecimento e do retorno. A experiência da criança transformou-se em brincadeira, por repetidas vezes, passando de uma posição passiva para uma ativa, podendo lidar com as pulsões tanto de vida, como de morte. Nessa perspectiva freudiana, o brincar caracteriza-se como um modo de expressão característico das crianças, ligado à possibilidade de elaboração de conflitos.

Ainda sobre o brincar e a elaboração psíquica, no texto Mal-estar na civilização, Freud (1930/1996) trata do antagonismo entre as exigências pulsionais e as restrições da cultura, sendo que uma das mais difíceis tarefas do indivíduo é a busca incessante pela felicidade. Esse conflito entre a satisfação das pulsões primitivas e as exigências civilizatórias leva-nos a relacioná-lo com o conceito de violência, na perspectiva freudiana.

Laplanche e Pontalis (2001) afirmam que a violência era definida, inicialmente, como pura manifestação da agressividade, algo que não poderia ser domado, sendo uma inclinação do instinto do homem a fim de fazer sofrer seus semeIhantes, como uma satisfação do desejo de destruição, e depois passou a ser problematizada também no campo social. Entendemos, portanto, que o conceito de violência envolve tanto o componente pulsional quanto o social, ressaltando o conflito entre a satisfação dos desejos primitivos e as exigências impostas pela civilização (Freud, 1930/1996).

Com a ampliação do conceito da violência - deixando de ser considerado como pura manifestação da agressividade -, relacionado ao campo social, poder-se-ia afirmar que as tendências destrutivas e violentas do humano podem ser mediadas e alcançar fins socialmente aceitos. Há, nesse processo de elaboração psíquica, um trabalho incansável da sociedade de amansamento pulsional, buscando aliviar o sujeito dessa tensão, já que a satisfação plena da pulsão é impossível (Júnior \& Besset, 2010).

No âmbito pulsional, a violência relaciona-se com os conceitos de pulsão de vida e pulsão de morte (Freud, 1920/1996). Em Além do Princípio do Prazer, foi a primeira vez que o termo pulsão de morte foi citado: Freud tecia ligações com a compulsão à repetição, sendo esta compulsão relacionada ao comportamento das crianças ao brincar e no tratamento psicanalítico. Ao brincar, a criança repete alguns movimentos que expressam suas pulsões hostis, agressivas 
e destrutivas, tentando elaborar possíveis experiências desagradáveis. Elas só repetem essa experiência porque tal ação envolve uma produção de prazer, de outro tipo, como uma tentativa de elaboração psíquica (Freud, 1920/1996).

Já para Winnicott (1987/2012), em Privação e Delinquência, a agressividade manifesta-se de maneira desviada, disfarçada, escondida, sendo difícil a identificação de suas origens. Trata-se de uma reação à frustração e também como uma das diversas fontes de energia do sujeito, pois cada pessoa lida de uma forma específica com ela, consciente ou inconscientemente. Essa se relaciona com a movimentação do indivíduo: inicialmente, como uma tendência da criança ao movimento buscando certo prazer muscular e, posteriormente, indo ao encontro de algum objeto. Não é, portanto, uma questão a ser curada, mas sim consentida.

Além disso, a agressividade relaciona-se ao processo de diferenciação entre o eu e o não eu. Winnicott (1987/2012) afirma que "a destruição primitiva ou mágica de todos os objetos está ligada ao fato de que (para a criança) o objeto deixa de ser parte de 'mim' para ser 'não-mim', deixa de ser fenômeno subjetivo para passar a ser percebido objetivamente" (p. 109), contrastando o objeto subjetivamente percebido e o objetivamente concebido.

A criança passa a amar e a odiar, ao mesmo tempo, vivenciando essa contradição. A agressividade relaciona-se à ambivalência amor-ódio, uma vez que o sujeito "só magoa aqueles de quem gosta muito" (Winnicott, 1987/2012, p. 95). 0 desafio é entender como o sujeito "encontrará uma forma de aproveitar essas forças agressivas para a tarefa de viver, amar, brincar e (finalmente) trabalhar" (Winnicott, 1987/2012, p. 108).

Para Winnicott (1975), o brincar é uma experiência criativa, merecendo ser estudado como um tema em si mesmo. 0 brincar vai sendo conquistado, a partir do encontro com o outro, já que o objetivo é trazer o sujeito de uma condição em que não é capaz de brincar para um estado em que é. 0 brincar é postulado a partir da existência de um espaço potencial entre o bebê e sua mãe (entre o mundo interno e a realidade externa), é aquilo que une e separa, ao mesmo tempo e paradoxalmente, expandindo-se para outras instituições sociais: da família à escola, por exemplo.

Winnicott (1975) afirma que a dimensão do brincar vai se ampliando para além de modo de expressão característico das crianças, estando relacionado à continuidade do ser. 0 brincar tem um tempo e um espaço, referindo-se à adaptação do outro, à capacidade de ir e vir - como uma maré, um ritmo contínuo -, tendo um tempo próprio, sendo algo conquistado pela criança. Esse espaço, por sua vez, é definido como um playground, um espaço potencial entre a realidade interna e externa, num movimento de vaivém. Ele é possibilitado por um ambiente que inspira confiança, pois tem o potencial de ser transicional, alternando entre a sensação de fusão inicial mãe-bebê e a percepção de diferenciação eu-outro.

O brincar, além disso, conduz e facilita os relacionamentos grupais, sendo que "as crianças brincam com mais facilidade quando a outra pessoa pode e está livre para ser brincaIhona" (Winnicott, 1975, p. 67). O autor ainda nos alerta sobre a disponibilidade que os adultos precisam ter com as crianças ao brincar: não significa que é necessário ingressar e interferir na brincadeira, pois quando o organizador se envolve de forma a administrar o brincar, corre o risco de desconsiderar a capacidade da própria criança se envolver com a atividade e tomar para si o que faz sentido. As crianças são sujeitos criativos que se comunicam ao brincar e aprendem brincando. "É no brincar, e talvez apenas no brincar, que a criança ou o adulto fruem sua liberdade de criação" (Winnicott, 1975, p. 79).

0 brincar permite também a integração do self. 0 bebê, que se encontra em um estado inicial de não-integração, ao sentir confiança e segurança no ambiente, vai se desenvolvendo rumo à integração (Winnicott, 1975). A transição do estado de não-integração para o estado de integração remete à evolução do funcionamento psíquico do princípio de prazer ao princípio de realidade, postulado por Freud (1920/1996). Com a introdução do princípio de realidade, o fantasiar, que começa nas brincadeiras infantis e se conserva em forma de devaneio nos adultos, abandona a dependência de objetos reais, possibilitando a criação e a imaginação. Essa noção de transicionalidade refere-se ao viver criativo, à maneira com que cada um encontra de estar vivo e lidar com a realidade interna e externa, construindo seu verdadeiro self.

O brincar é também considerado como um direito social da criança (Brasil, 1990), indo além de uma necessidade ou característica. Pedroza (2012) ressalta que a brincadeira se caracteriza como uma experiência criativa dos sujeitos que permite uma melhor aproximação dos educadores com as necessidades das crianças. Pacheco (2015) acrescenta que a brincadeira é um elemento fundamental no desenvolvimento do sujeito, não podendo ser considerada pelas escolas apenas como um instrumento didático, já que é a principal mediadora dos processos de aprendizagem e de desenvolvimento das crianças.

Desse modo, o brincar é tido como uma dimensão fundamental do processo de desenvolvimento humano, em contextos formais e informais, pois brincando as crianças são capazes de conquistar "competências sociais e pessoais fundamentais para a sua vida cotidiana com repercussão ao longo da vida, (re)conhecem suas capacidades e limites, aprendem a superar-se, edificam suas estruturas mentais e emocionais, preparando-se para assumir o(s) seu(s) papel(éis) na sociedade" (Palma, 2017, pp. 204-205). 


\section{MÉTODO}

Nesta pesquisa, foi utilizada a metodologia qualitativa e as informações foram construídas a partir das falas e associações dos sujeitos participantes, bem como da utilização de brincadeiras e desenhos das crianças. 0 método psicanalítico de investigação foi mobilizado, a fim de realizar articulações e interpretações em transferência, guardados os devidos limites da pesquisa participante.

Segundo Bogdan e Biklen (1994), a pesquisa qualitativa é um processo de produção de conhecimento permanente, na medida em que, durante seu desenvolvimento, novas questões podem surgir e indicar um caminho diferente, implicando em uma postura flexível do pesquisador. Nesse sentido, tal postura também é exigida quando o pesquisador lança mão dessa abordagem ao se aproximar da visão de mundo das crianças.

A pesquisa com (e sobre) crianças pressupõe que elas são sujeitos de direitos e de desejos: não se trata de avaliálas ou definir suas especificidades, mas sim buscar conhecer e valorizar aquilo que elas pensam e sentem. Entrevistas e/ou oficinas são vias importantes, conforme Trautwein (2010), para estudar temas que não são bem formulados por elas próprias. Já Cruz (2010) acrescenta outros modos, igualmente válidos, para se aproximar da visão de mundo das crianças: o uso de desenhos, jogos, brincadeiras, observações, arte, imagens e histórias.

A pesquisa foi realizada em uma escola pública de educação infantil, localizada em uma Região Administrativa (RA) do Distrito Federal (DF). É considerada uma escola inclusiva que, em 2013 (ano em que a pesquisa foi realizada), atendia a aproximadamente 400 crianças entre zero e cinco anos. No que diz respeito ao ambiente da escola, pareceu-nos agradável por ser amplo, colorido e arejado; um pátio no centro abarcava as nove salas à sua volta, formando um grande quadrado. Ao fundo, por meio de um corredor, as crianças tinham acesso a um parque relativamente grande, uma mangueira alta e arbustos, com vários brinquedos espalhados (escorregadores, balanços, gira-gira e trepa-trepa), e um parquinho de areia.

O primeiro contato das pesquisadoras foi com a diretora da escola, que se mostrou bem interessada na pesquisa. Propusemos apresentar os objetivos do estudo em um momento no qual todos os funcionários da escola estivessem reunidos. Uma vez nossa sugestão aceita pela diretora, fomos convidadas a retornar em uma reunião de coordenação pedagógica e apresentamos a nossa proposta, perguntando qual professor ou professora se sentiria à vontade para participar. Ninguém demonstrou interesse, dizendo que iam pensar e depois entrariam em contato.

Quase uma semana depois, a diretora telefonou para co- municar que poderíamos acompanhar a turma de Ana (nome fictício, assim como os demais que aparecem neste trabalho), professora regente do primeiro período da educação infantil. Dessa forma, ao longo da pesquisa, relacionamo-nos com as 15 crianças dessa turma para a realização dos dois dias de observação participante e das quatro oficinas lúdicas.

Desde o primeiro contato com a instituição, fomos bem recebidas. A diretora e a coordenadora pedagógica, especialmente, mostravam-se interessadas e disponíveis, almejando que uma relação harmoniosa ocorresse entre a escola e as pesquisadoras. No entanto, Ana contou-nos, já no final da pesquisa, que nenhuma professora manifestou vontade de participar e, então, a diretora fez um sorteio para escolher acontecendo o oposto do que foi sugerido pelas pesquisadoras. Ana parecia chateada, não queria ter participado daquelas atividades. No início, era perceptível seu medo e sua desconfiança em relação ao que aconteceria com a turma, mas, depois, ela foi se envolvendo e contribuindo com o estudo: um desencontro inicial foi transformado em encontros frutíferos.

Inicialmente, realizamos a leitura e a análise do projeto político-pedagógico (PPP) da escola, que foi elaborado no ano de 2012 e disponibilizado para nós, pesquisadoras, em 2013. Depois, demos início à pesquisa empírica: dois dias de observação participante no turno matutino, das 7h30 às $12 \mathrm{~h} 30$, e quatro oficinas lúdicas com as crianças, que aconteceram na própria sala de aula, como proposto pela professora, com a duração de aproximadamente uma hora. Nesses dias, as pesquisadoras iam apenas para a realização das oficinas, seguindo também a sugestão da professora regente.

Para analisar as informações construídas na pesquisa, utilizamos a análise de conteúdo, proposta por Bardin (1977/2010). Foi feita uma categorização das informações, iniciando com uma pré-análise, uma exploração do material, inferências e interpretações. Foi importante dividir e reagrupar o material em categorias analíticas - "encontros e desencontros entre o escrito no PPP e a vivência na observação participante"; e "as concepções de crianças sobre violência", apresentadas nos resultados -, considerando o contexto de sua produção para a apreensão dos significados implícitos. $\mathrm{Na}$ fase de pré-análise, transcrevemos as informações da pesquisa e fizemos uma leitura flutuante desse texto; posteriormente, os temas emergiram a partir das unidades de significação (Bardin, 1977/2010).

\section{RESULTADOS EDISCUSSÃO}

Encontros e desencontros entre o escrito no PPP e a vivência na observação participante

O processo de leitura do PPP permitiu o conhecimento mais detalhado da estrutura e do funcionamento da escola, 
bem como de sua proposta político-pedagógica. Os grandes eixos norteadores constituem-se no "brincar; na inclusão; na formação de cidadãos; na formação da consciência ecológica; na construção do leitor crítico, reflexivo e atuante; na democratização das ações e na formação do cidadão apto para atuar e transformar seu ambiente de convivência".

O trabalho pedagógico, de acordo com o documento, baseia-se em uma postura de respeito à criança, objetivando estimular a criatividade e a autonomia, além de incorporar o brincar na sua prática em sala de aula, estabelecer vínculos afetivos de troca dentro da comunidade escolar, entre outros. Para atingir tais objetivos, busca-se usar a literatura, priorizar o brincar como atividade essencial, acompanhar o desenvolvimento de cada aluno com fichas de acompanhamento e relatórios semestrais, além de valorizar a formação ética, estética e a ludicidade.

Por meio da observação participante realizada na turma da professora Ana e em outros momentos da pesquisa, percebemos que, apesar de essa escola apresentar um PPP bem elaborado e reflexivo, seus objetivos ainda estão distantes de serem atingidos. No primeiro dia de observação, enquanto as crianças brincavam, queixavam-se e reclamavam dos colegas com frequência, Ana chamava-os, dizendo: "vem cá que eu resolvo o seu problema com ele... Como vocês brigam! A professora é uma só!". Ela assumia a resolução dos conflitos das crianças, não dando espaço para que elas desenvolvessem sua autonomia na negociação deles, contrariando uma das metas educacionais assinaladas no PPP, que é construir a autonomia dessas crianças.

Ademais, é imprescindível o respeito ao tempo de cada criança, bem como o incentivo pela conquista de sua autonomia, pois, como Winnicott (1975) afirma, a agressividade está ligada ao processo de diferenciação entre o eu e o nãoeu, tornando um desafio entender como o sujeito aproveita suas forças agressivas para viver, amar e brincar. Se cada sujeito lida de forma particular com seus impulsos violentos e agressivos, faz-se necessária a existência de um ambiente acolhedor e que inspire confiança, sobretudo para oferecer ajuda quando é preciso, bem como para incentivar a resolução de conflitos de cada sujeito, de maneira autônoma.

A brincadeira, que no PPP é valorizada como atividade fundamental na vida da criança (na escola), era restrita a algumas situações e espaços delimitados, parecendo se resumir ao pátio, ao parque e à hora do recreio. Pedroza (2012), Pacheco (2015) e Palma (2017) ressaltam que a brincadeira é um elemento fundamental no desenvolvimento do sujeito, não podendo ser considerada pelas escolas apenas como um instrumento didático, pois ela é a principal mediadora dos processos de aprendizagem e de desenvolvimento das crianças, sendo também uma atividade criativa entre os sujeitos.
Em sala de aula, espaço legítimo para as brincadeiras, segundo o documento, elas não conseguiam cumprir suas finalidades pedagógicas: no início do dia, por exemplo, com as crianças, sentadas em suas cadeiras e distribuídas em grupos de quatro alunos, a professora propunha a atividade do "quantos somos?", para aprenderem os números e as quantidades. Mas, antes mesmo das crianças brincarem com esse tema e aprenderem de maneira lúdica e significativa, a professora já antecipava, dizendo: "dois, quatro, seis, oito, dez, doze... ah, hoje vieram só doze", o que demonstra um raciocínio mais abstrato, elevado para aquelas crianças, que só observavam e não entendiam a atividade proposta.

Winnicott (1975) ressalta que os adultos precisam estar disponíveis para brincar com as crianças, tendo um cuidado para não precipitar os conteúdos, tampouco administrar e controlar os jogos infantis, almejando preservar a autonomia e estimular a espontaneidade de cada sujeito. Assim, a própria criança poderá se envolver com o brincar e tomar para si o que faz sentido, explorando seu potencial criativo, tendo seu tempo e espaço respeitados.

Sobre a rotina, as crianças tinham um roteiro de atividades pré-estabelecido, seguindo esta ordem: momento da entrada; ida ao banheiro; entrada na sala de aula; distribuição nas cadeiras (em mesas de quatro lugares, as crianças deveriam se acalmar, em silêncio, abaixando a cabeça e fechando os olhos); contagem de quantos somos; percepção de como está o dia; atividade sugerida pela professora (que poderia ser a atividade de pintura, contação de história, entre outras), realizada pelas crianças ainda em suas mesas; lanche trazido pela merendeira, que era servido para cada criança; momento do recreio; volta para a sala de aula e relaxamento. Em segui$\mathrm{da}$, as atividades variavam, a partir de um leque maior de possibilidades: ir ao parque, contar história, fazer uma apresentação do que quisessem naquele dia, ou, às sextas-feiras, brincar com os brinquedos trazidos de casa.

0 momento de entrada pareceu ser um dos mais interessantes para as crianças, em que todas elas e as educadoras se encontravam: um momento exclusivo de interação entre todos os atores da escola, mais leve, divertido e descontraído. No primeiro dia de observação participante, comemoravam o dia do circo e, nesse primeiro período, havia uma professora fantasiada de palhaço. As crianças interagiram com as demais turmas e educadoras, por alguns minutos, e depois seguiram para suas salas, junto à professora regente. Fomos acompanhando a turma, inclusive ao banheiro, onde uma aluna perguntou: "vamos fazer xixi?" e Ana respondeu: "não, vamos colher as flores que estão no banheiro...". A criança pareceu não entender a fala da professora, fazendo um gesto de incompreensão.

Nessa cena, a forma com que Ana respondeu nos pareceu irônica, sem sentido ao contexto da aluna, demonstrando certa zombaria, desprezo e desdém. A criança, dessa manei- 
ra, não foi respeitada em seus direitos de indagar e de receber respostas verdadeiras às suas questões. Essas perguntas podem permitir o diálogo e relações de respeito, que possibilitam a construção da subjetividade das crianças (Sousa, 2014).

Ao entrarem na sala, as crianças sentaram-se, fecharam os olhos e abaixaram a cabeça nas mesas para "se acalmarem". Fizeram a atividade de perceber como está o dia. Ana perguntou: "que dia é hoje?". As crianças responderam: "segunda", e ela escreveu no quadro: "sexta", dizendo que eles haviam errado a resposta. Ainda voltada para o quadro, perguntou: "vocês notaram como está o céu hoje?", e as crianças disseram: "sim". Ana prosseguiu: "muito bem, está nublado, com nuvens", desenhando as nuvens, antecipando-se mais uma vez à resposta das crianças.

Ressaltamos que se trata de uma professora com 46 anos - na época em que a pesquisa foi realizada -, formada em pedagogia, além de ter feito o magistério e um curso para trabalhar com os anos iniciais. Ana trabalha nessa escola há nove anos e nos contou que já estava cansada da profissão, desejando a aposentadoria, não queria mais trabalhar com crianças por exigir "um grande esforço do corpo e da mente". No entanto, ela não havia conseguido uma vaga para trabaIhar com outro público. Além disso, não havia um desejo dessa professora em participar da pesquisa - o que houve foi um sorteio da diretora que acabou selecionando Ana como participante do estudo. Essas informações permitem-nos entender algumas falas e atitudes de Ana, levada pelo cansaço, pela falta de motivação e desejo de não estar naquele lugar. Vale retomar aqui as afirmações de Winnicott (1975), quando ele defende que o brincar parte do encontro com o outro e o trabalho é restaurar a capacidade daquele que não é capaz de brincar para uma condição que o é. Seria necessário, desse modo, restaurar a capacidade brincante de Ana.

No recreio, um momento de descanso para as professoras, as crianças brincavam de forma livre: corriam, davam piruetas, rolavam, caíam, levantavam e interagiam entre si. Como era sexta-feira, elas podiam levar brinquedos de casa. A "hora dos brinquedos" acontecia logo após o relaxamento e era um momento muito esperado por elas. Mais uma vez, compartilhavam entre si e negociavam quando queriam brincar com o que os colegas haviam levado. No entanto, quando acontecia algum conflito, Ana interferia e dizia: "cada um brinca com o seu, para não ter problema", não estimulando, nessa outra situação, a construção da autonomia pelas crianças.

Antes de irmos embora, como era o dia do palhaço, Ana propôs que fizéssemos pinturas em nossos rostos. Inicialmente, as pesquisadoras e Ana pintavam as crianças, que formavam filas e demonstravam empolgação com a atividade. Depois, as próprias crianças foram pintando umas às outras, incluindo as pesquisadoras. Ana preferiu não ser pin- tada e foi respeitada. Foi um momento alegre e de descontração, em que as crianças exploravam sua criatividade e seu potencial brincante.

No segundo dia de observação participante, a rotina das crianças foi diferente. Logo depois do momento de entrada, as crianças passaram no banheiro e já foram para o parque, até a hora do lanche. Naquela semana, tinha tido apenas dois dias de aula, devido às paralisações dos educadores, e, por esse motivo, Ana resolveu levá-las ao parque, dizendo: "como tiveram pouca aula essa semana, não adianta fazer muito trabalho, vamos para o parque mesmo!”. Em sua fala, há uma desvalorização do momento do parque, não o reconhecendo como uma possibilidade de realizar um trabalho com as crianças. Em nossa vivência, percebemos o oposto: as crianças brincaram, escorregaram, balançaram, foram ao gira-gira e correram. Elas aprendiam a negociar seus conflitos, criavam novas brincadeiras, comunicavam-se e ajudavam-se, o que constituiu um ambiente precioso e propício à situação de criação e aprendizado.

Ao final desse segundo dia, Ana tinha programado-se para colocar uma música, visando ao relaxamento das crianças, antes de irem embora. Sentadas nas cadeiras, com a cabeça baixa e os olhos fechados, elas esperavam a música do relaxamento. Porém o som não funcionou e Ana disse: "então, vamos todos aqui pra frente, já que o som não funciona, vamos cantar". Era uma música comum para as crianças, pois todas sabiam a letra. Foi um momento alegre e divertido, a partir de uma proposta que, a princípio, não tinha dado certo. Criou-se um momento de interação diferente do planejado: foi uma situação prazerosa, na qual as crianças puderam se expressar, sem o controle do corpo nas carteiras.

Esses momentos permitiram uma forma de lidar com o inesperado, com a surpresa e com o novo, possibilitando às crianças sair da rotina e, às professoras, aproximarem-se de seus alunos de modo diferente. Entre encontros e desencontros sobre o escrito no PPP e a vivência na observação participante, pudemos observar lampejos de situações que propiciavam descontração, diversão, brincadeiras e inventividade. Como Palma (2017) afirma, esses momentos de brincadeiras e de diversão constituem uma dimensão fundamental no processo de desenvolvimento humano. As crianças conquistam suas competências pessoais e sociais, sendo o brincar uma atividade muito séria, como já afirmara Freud (1908/1996).

\section{CONCEPÇÕES DE CRIANÇAS SOBRE VIOLÊNCIA E A RELA- ÇÃO COM O BRINCAR}

Foram realizadas quatro oficinas com o grupo de $15 \mathrm{cri}-$ anças de quatro e cinco anos de idade, alunos da professora Ana, com duração aproximada de uma hora cada. Ana prefe- 
riu nos deixar a sós e teve esse momento como um tempo de descanso. Ao mesmo tempo, passava por vezes perto da sala de aula para verificar se estava tudo bem.

Para ir conhecendo melhor as crianças, construímos uma primeira oficina mais livre, perguntando às crianças o que gostavam de fazer. Elas responderam que gostam de brincar, dar rolada e cambalhota, brincar de bambolê, cantar, ir ao cinema e à chácara, brincar de pique esconde, nadar e correr. Depois, propusemos que elas fizessem um desenho livre do que mais gostavam, explorando suas expressões artísticas. Nesse momento, algumas crianças estavam envolvidas com a atividade proposta, porém outras já demonstravam que não queriam mais desenhar, movimentando-se pela sala de aula.

Ao guardar os materiais que estavam sendo usados, algumas crianças corriam pela sala de aula. Pedimos que elas se sentassem em roda para contar o que haviam desenhado. Algumas falaram, mas outras continuaram correndo, gritando e dando piruetas, expressando-se por meio de seus corpos. Mesmo havendo pedido que as crianças demonstrassem o que gostavam de fazer, essas manifestações corporais nos criaram um desconforto e preocupação. Admitimos a dificuldade em lidar com essa expressividade e em criar um espaço que possibilitasse a comunicação das crianças pelo seu corpo e seus movimentos, que ainda são mais presentes na linguagem delas (Sousa, 2014).

No momento em que as crianças se movimentavam pela sala, Murilo deu uma pirueta e seu pé pegou no rosto de Sabrina, que se assustou e chorou muito. Murilo pediu desculpas, no entanto Sabrina continuava chorando. Eva mostrou-se preocupada, perguntando se ela tinha se machucado, e Sônia queria saber onde o pé dele tinha batido. Ainda assim, as crianças corriam, se movimentavam, fazendo montinhos, subindo um em cima do outro e segurando umas às outras. $A$ professora Ana, ao se deparar com essa situação enquanto passava perto da sala, voltou e pediu que as crianças se sentassem e obedecessem.

Depois que as crianças se sentaram, perguntamos o que elas achavam que deveria ser feito quando acontecia alguma situação como aquela. Sônia disse: "pede desculpa"; outra criança falou: "fica triste e faz carinho". Ainda perguntamos: "vocês gostam é de correr, dar piruetas e fazer bagunça igual fizeram agora?". Afonso, parecendo estar assustado e indignado, por meio de seus gestos e expressão corporal, respondeu: "não! A gente não faz bagunça! A gente brinca!".

Esse diálogo acabou por evidenciar a nossa concepção sobre essas expressões corporais como sendo bagunça, demonstrando a diferença em relação à concepção das crianças, o que foi fundamental para o processo da pesquisa. Esse fato salientou a importância de se ouvir todos os sujeitos nas escolas, sobretudo as crianças, para uma melhor compreensão de suas interpretações (Sousa, 2014).
No segundo dia de oficina era o Dia Nacional do Livro Infantil, criado em homenagem ao Monteiro Lobato, e, quando chegamos à escola, as crianças ainda estavam no momento da entrada, escutando uma história sobre índios, narrada e interpretada por algumas educadoras. Por coincidência, também havíamos levado histórias infantis para a realização de nossa oficina.

Após o momento da entrada, as crianças passaram no banheiro, como de costume, e depois foram para a sala de aula, junto à Ana. Assim que entraram na sala, Ana retirou-se e iniciamos a oficina, propondo que sentássemos em roda para fazer alguns combinados, como de não poder correr dentro da sala. As crianças concordaram e demonstraram curiosidade sobre o que havíamos levado. Mostramos os nossos livros que foram escolhidos de maneira aleatória: não era necessário ter algum conteúdo explícito sobre violência.

As crianças formaram pequenos grupos a partir do interesse pelos livros, escolhendo apenas dois do que havíamos levado: $A$ branca de neve e 0 ratinho, o morango vermelho maduro e o grande urso esfomeado. A leitura das histórias permitia que expressassem suas ideias e opiniões, indo além de uma possível interpretação de texto e de uma realidade concreta dos fatos. Elas imaginavam, criavam e repensavam as situações, além de possibilitar suas manifestações sobre aquilo de que gostam e não gostam, posicionando-se em relação ao que estava sendo contado.

Sobre as histórias infantis e os contos de fada, Bettelheim (2001) afirma que, a partir dessa literatura, é possível abordar diferentes assuntos (entre eles a violência), a partir dos recursos que as crianças possuem, sendo, assim, um instrumento de mediação. Acreditamos, portanto, ser importante que a criança encontre maneiras de lidar com seus conflitos, o que pode ser feito a partir do contato com as histórias infantis.

Já na terceira oficina, propusemos que as crianças falassem sobre o que pode e não pode na escola; o que acham legal e o que não acham legal. Notamos que o obedecer foi citado tanto em relação ao que pode se fazer na escola quanto ao que não é legal. o bagunçar, por sua vez, foi citado, predominantemente, a respeito do que não se pode fazer na escola. Acerca do que as crianças acham legal, a resposta unânime foi: brincar. A partir disso, ressaltamos que, para conversar sobre violência, especificamente, na quarta oficina, os dois dias inteiros de observação participante e as três primeiras oficinas foram essenciais para o fortalecimento do nosso vínculo com as crianças.

$\mathrm{Na}$ quarta oficina, sentados em roda, iniciamos, dizendo: "hoje vamos falar de um assunto que é muito sério e difícil de falar. Tem um monte de gente que prefere nem falar. Quero que vocês me ajudem a pensar nesse assunto difícil... Vocês sabem o que é violência?". Durante a conversa, nem todas as 
crianças se manifestaram em todos os momentos, enquanto algumas falaram, outras preferiram ficar escutando. Hugo disse que não e Sônia falou: "eu sei, é polícia". Outras crianças falaram que violência é: "arma", "de matar", "de lutar", "delegacia", "revólver" e, também, "polícia".

Depois, perguntamos: "vocês querem falar sobre como é violência na escola?". Eva disse: "violência de chegar polícia aqui". Continuamos a conversa perguntando: "já chegou polícia aqui?". Ela respondeu que não, demonstrando certo medo, e ainda disse: "tenho medo do homem do saco". Vinícius disse baixinho: "ele não existe". No entanto, perguntamos: "como que é o homem do saco?". Eva respondeu: "o homem do saco... Ele pega pessoas". Isabela completou: "tenho medo de ficar no lixo". Sônia ainda disse: "aí o pai dela não vai saber onde ela está".

Além disso, indagamos: "como seria violência na casa de vocês?". Eva respondeu: "na minha casa não tem lobo" e questionamos: "não tem lobo? Então não tem violência?". Vinícius disse que tem sim e perguntamos: "como?". Ele respondeu: "quando os adultos brigam". Nesse momento, Afonso falou: "eu gosto da minha mãe quando ela beija em mim". Sônia ainda disse que violência na casa dela é: "quando a polícia chega".

Propusemos, em seguida, que as crianças brincassem de massinha, tentando representar a violência. As crianças nomearam seus objetos criados com as massinhas da seguinte forma: bola de futebol, cobra, polícia, carro de polícia, arma, delegacia, pizza, calça, sanduíche, macarrão, pingo e gol. Houve uma repetição daquilo que foi dito pelas crianças no início da oficina, com o tema da polícia aparecendo a todo o momento.

Depois, propusemos o jogo do desenho da violência, dizendo: "agora vocês vão tentar desenhar o que é violência e depois cada um vai falar o título do seu desenho para expor no nosso mural". Bárbara disse que preferia não desenhar e queria continuar brincando com as massinhas, e assim foi feito. As outras crianças desenharam e nomearam da seguinte maneira: "carro de polícia e arma", "delegacia", "menina saindo do prédio e viu a polícia", "pop star", "caminhão", "princesa" e "polícia". Notamos que elas gostaram da atividade e de entregar os desenhos para que pudéssemos escrever seus nomes e títulos. Mesmo tendo aparecido outros elementos, o tema da polícia continuou se repetindo.

A respeito da relação entre infância e violência, Postman (1999) afirma que a partir dos séculos XVI e XVII a infância foi reconhecida como uma fase específica do desenvolvimento humano - as crianças não eram mais miniaturas de adultos, mas sim seres em desenvolvimento, com suas características próprias. Tornaram-se alvo de cuidados diferenciados, com vestimentas, linguagem e literatura próprias, sendo, portanto, afastadas do mundo adulto. Sexualidade, dinheiro, doença, morte e violência, passaram de segredos que não pertenceriam ao universo infantil a conteúdos revelados paulatinamente às crianças.

Com base na leitura freudiana, o autor pontua que não pode haver civilização se os impulsos não forem controlados, em especial os agressivos e os de satisfação imediata. Isso não significa que as crianças devem estar protegidas e separadas de todo e qualquer conhecimento acerca da violência (Postman, 1999). Entretanto, como Bettelheim (2001) afirma sobre os contos de fada, é possível revelar a existência do mal por meio de recursos que as crianças sejam capazes de assimilar, à própria maneira.

A escola na qual a pesquisa foi realizada está inserida em um contexto considerado não-violento, próximo a paradas de ônibus, estação de metrô, comércio e boas residências. Os alunos que frequentam a escola possuem um bom vocabulário, boas vestimentas e materiais escolares. Por ser uma escola inclusiva, é um ambiente com crianças e adultos com realidades diversas, sem histórico de episódios de atos de violência, sobretudo da polícia. Em certo momento da pesquisa, uma professora de outra turma até mencionou que deveríamos ter ido à outra escola, pois naquela "não havia violência para pesquisar".

De acordo com o nosso referencial teórico psicanalítico, podemos afirmar que falar de polícia, arma, delegacia é um modo de as crianças manifestarem, inconscientemente, a violência e a autoridade como constituidoras e impeditivas da realização plena das pulsões e dos desejos na sua forma primitiva (Sousa, 2014). Em relação à teoria freudiana acerca do brincar, Oliveira e Fux (2014) afirmam que as brincadeiras podem criar mundos imaginários e (re)viver o mundo dos adultos, como ao brincar de polícia-ladrão. Logo, pensar no discurso dessas crianças atrelado à polícia permite-nos relacioná-lo a esses jogos que se ligam ao desejo infantil de se tornar adulto e também à tentativa de elaboração psíquica.

No final da quarta oficina, algumas crianças quiseram voltar a brincar com as massinhas e outras preferiram continuar desenhando, o que aconteceu em clima descontraído e tranquilo. Para encerrar, propusemos que as crianças falassem como seria uma escola legal. Algumas disseram que não poderia faltar massinha e nem brinquedo. Sônia se levantou e nos abraçou, demonstrando que não poderiam faltar abraços na escola.

Com esse gesto, antes de encerrar nosso encontro, as pesquisadoras pediram um abraço a todas as crianças para se despedir. Todas elas abraçaram, ao mesmo tempo, demonstrando uma troca de carinho. Depois, cada uma deu outro abraço, individualmente. Ao final, as pesquisadoras ainda agradeceram às crianças e à professora Ana (que se aproximava da sala de aula, no horário combinado) pela disponibilidade e pela oferta do espaço. 


\section{CONSIDERAÇÕES FINAIS}

A pesquisa empírica reforçou a pertinência em tecermos relações entre a violência e o brincar, entendendo-o, a partir da psicanálise freudiana, como uma das maneiras de elaborações de conflitos e de conteúdos ligados à violência. Além disso, com base na leitura winnicottiana, o brincar é também considerado uma experiência criativa, relacionada ao sentimento de continuidade do ser e à noção de transicionalidade.

Sobre a violência, entendemos que existem diversas formas de pensar, estudar e lidar com ela, pois é uma questão multifacetada e cada sujeito a vivencia singularmente, afetando e sendo afetado pela história, cultura e sociedade que o constituem. Com nossa experiência nessa escola, especificamente, foi possível evidenciar que a concepção das crianças do primeiro período da educação infantil foi atrelada, sobretudo, à polícia e a outros elementos relacionados a ela. Essas foram associações feitas por esse grupo de crianças, podendo haver outras concepções diferentes, a depender do contexto de cada uma e do acesso às informações da cultura.

Ademais, concebemos que o brincar é uma das maneiras possíveis para lidar com o fenômeno da violência. Pontuamos ainda que nem todas as brincadeiras de lutinha ou de briga precisam ser interpretadas como violência em potencial. O próprio ato de brincar pode permitir a elaboração de conflitos e possibilitar a expressão criativa das crianças.

A pesquisa evidenciou ainda a importância da criação de espaços para que as crianças possam ser escutadas e respeitadas em seus direitos. Pensar em atividades dirigidas para elas é importante; todavia, para além delas, acreditamos ser fundamental o brincar junto e envolver-se com as atividades, compreendendo e respeitando o tempo de desenvolvimento de cada uma.

O brincar é, portanto, uma possibilidade criativa do sujeito encontrar contenção, mediação e representação a elementos da cultura, sendo capaz de lidar, por exemplo, com a violência e, além disso, elaborá-la. Na perspectiva freudiana, a experiência de frustração das crianças pode transformar-se em brincadeira, assim como no jogo do fort-da, passando de uma posição passiva para uma ativa. Ao brincar, torna-se possível lidar com as pulsões, tanto de vida, como de morte, ligado a essa possibilidade de elaboração de conflitos (Freud, 1920/1996).

Ademais, não se pode ignorar a contribuição das brincadeiras como forma de a criança exprimir seus sentimentos agressivos e violentos, que fazem parte de sua vida. A brincadeira é um fenômeno "universal e é própria da saúde: o brincar facilita o crescimento e, portanto, a saúde; o brincar conduz aos relacionamentos grupais" (Winnicott, 1975, p. 63), caracterizando-se como uma experiência criativa dos sujei- tos.

Nas escolas, especificamente, entendemos que as crianças precisam brincar, movimentar seus corpos e sair de seus lugares, de forma espontânea, pois tais manifestações são uma das principais maneiras de se desenvolverem. Além disso, o brincar permite a criação de um espaço acolhedor e descontraído que pode facilitar a consolidação do vínculo entre crianças e adultos, bem como potencializar as suas possibilidades de desenvolvimento.

\section{FINANCIAMENTO}

CNPQ.

\section{REFERÊNCIAS}

Bardin, L. (2010). Análise de conteúdo. São Paulo: Edição 70. Trabalho original publicado em 1977.

Barros, M. (2003). Memórias inventadas: A infância. São Paulo: Planeta.

Bettelheim, B. (2001). A psicanálise dos contos de fadas. Rio de Janeiro: Paz e Terra.

Bogdan, R. C., \& Biklen, S. (1994). Investigação qualitativa em educação. Portugal: Porto Editora LDA.

Pacheco, M. N.P. (2015). O brincar na escola: Possibilidades de desenvolvimento em salas de recurso. (Dissertação de mestrado). Recuperado de http://repositorio.unb.br

Brasil (1990). Estatuto da Criança e do Adolescente. Brasília: Edições Câmara.

Cruz, S. H. V. (2010). Prefácio - ouvir crianças: Uma tarefa complexa e necessária. In M. P. R. Souza (Ed.) Ouvindo crianças na escola: Abordagens qualitativas e desafios metodológicos para a psicologia (pp. 11-21). São Paulo: Casa do Psicólogo.

Freud, S. (1996). Além do princípio do prazer (J. Salomão, Trad.).Em J. Strachey (Ed.),Edição standard brasileira das obras psicológicas completas de Sigmund Freud (Vol. 18, pp. 12-75), Rio de Janeiro: Imago. Trabalho original publicado em 1920.

Freud, S. (1996). Escritores criativos e devaneios(J. Salomão, Trad.).Em J. Strachey (Ed.), Edição standard brasileira das 
obras psicológicas completas de Sigmund Freud (Vol. 9, pp. 132-143), Rio de Janeiro: Imago.Trabalho original publicado em1908.

Freud, S. (1996). Mal-estar na civilização(J. Salomão, Trad.).Em J. Strachey (Ed.),Edição standard brasileira das obras psicológicas completas de Sigmund Freud (Vol.21, pp. 66-148). Rio de Janeiro: Imago. Trabalho original publicado em 1930 .

Júnior, J. N. S., \& Besset, V. L. (2010). Violência e sintoma: 0 que a psicanálise tem a dizer? Fractal: Revista de Psicologia, 22(2),p. 323-336.http://dx.doi.org/10.1590/S198402922010000800008

Laplanche, J., \& Pontalis, J.B. (2001). Vocabulário de Psicanálise ( $\left.4^{\mathrm{a}} \mathrm{ed}\right)$. São Paulo: Martins Fontes.

Oliveira, H. M., \& Fux, J. (2014). Considerações psicanalíticas sobre os jogos de esconder: Do puti ao esconde-esconde. Revista Ágora, 17(2)p. . http://dx.doi.org/10.1590/S151614982014000200007

Palma, M. S. (2017). Representações das crianças sobre o brincar na escola. Revista Portuguesa de Educação, 30(2), p. 203-221. http://dx.doi.org/10.21814/rpe.8243

Pedroza, R. L. S. (2012). Infância e professores no espaço da brincadeira: Possibilidade de formação. Em L. H. Pulino; S. Gadelha (Eds.),Biopolítica, escola e resistência: Infâncias para a formação de professores (pp. 227-239). Campinas: Editora Alínea.

Postman, N. (1999). O desaparecimento da infância. Rio de Janeiro: Graphia.

Trautwein, C. T. G. (2010). A dor e a delícia de entrevistar crianças na construção de um procedimento metodológico infantil. Em M. P. R. Souza (Ed.),Ouvindo crianças na escola: Abordagens qualitativas e desafios metodológicos para a psicologia (pp. 257-277). São Paulo: Casa do Psicólogo.

Sousa, T. R. (2014). As concepções de crianças de educação infantil sobre a violência: Um estudo a partir da psicologia e da psicanálise.(Dissertação de mestrado). Recuperado de http://repositorio.unb.br

Winnicott, D. W. (1975). O brincar e a realidade. Rio de Janeiro: Imago Editora.
Winnicott, D. W. (2012). Privação e delinquência (5a ed.). São Paulo: Editora WMF Martins Fontes. Trabalho original publicado em 1987.

Recebido em: 25/10/2017 Primeira decisão editorial em: 08/03/2018 Aceito em: 25/03/2018 